\title{
Social Media and Student Online Aggression: A Case Study at Madrasah Aliyah Negeri (MAN) 2 Bogor City, West Java
}

\author{
Mulyana \\ \{yana.litbangjkt@gmail.com\} \\ Religious Research, Development and Training Agency, Ministry of Religious Affairs, \\ Jl. Rawa Kuning No. 6, Pulogebang, Cakung, Jakarta Timur, Indonesia 13950
}

\begin{abstract}
This paper presents and discusses the results of a case study of student online aggression on social media. The study examines the following issues: (1) How frequent is online aggression among students? (2) What are forms of expression used to commit online aggression? (3) What are policies the school and student families have to prevent and reduce online aggression? This case study revealed that the frequency of social mediafacilitated aggression varied according to the role of a student in aggression: as a witness, a victim or a perpetrator. The highest frequency of student online aggression in social media was reported by witnesses, followed by victims and perpetrators. Cursing/swearing words were the most frequent expression used by students while threatening words were the least frequent. Both the school and families have no specific policies to prevent and reduce student online aggression.
\end{abstract}

Keywords: Madrasah Aliyah, Student Online Aggression, School-Family Policies, Social Media

\section{Introduction}

Student violence has been one of the recurring social problems in Indonesia. After declining between 2014 and 2016, the number of student brawl (tawuran pelajar) incidents, one of the most common student violence, have been on the rise since 2017. Indonesian Child Protection Commission (KPAI) reported that in 2014 student brawls accounted for 24 percent of the total number of violence involving children. The figure decreased to $17.9 \%$ in 2015 and $12.9 \%$ in 2016. However, while in 2017 the percentage remained the same as the previous year, it increased to $14 \%$ by September 2018 [1]. KPAI also recorded that 202 children got into trouble with the law due to their involvement in student brawls during 2017-2018. In addition, there were 74 cases of possession of sharp weapons by adolescents [2].

Student brawls become the most striking student aggressive acts because these acts have received frequent media coverage and caused violent impacts on persons and properties. However, student aggressive behavior is actually not limited to physical violence such as fights, brawls, and property damage. More subtle and invisible aggression, such as bullying and verbal aggression, is indeed more prevalent.

In a 2014 survey of 3,633 senior high school students in the area of Greater Jakarta, 22.6 percent reported they had experienced light-to-moderate physical aggression from other students (being pushed, kicked or hit), while 3.62 percent had got more serious attacks (with 
blunt or sharp weapons). In the same survey, more than half of respondents reported they had been victims of verbal aggression of various types (being mocked, got bad calling or harsh words). This survey was conducted in 8 cities, including Depok, Tangerang, Bekasi, and five cities in the Province of Special Region of Jakarta. Population of this survey were students of senior high schools, state-owned and private, from all grades. 3,633 students were randomly selected as samples using a proportionate stratified random sampling technique. Estimated margin of error for this survey was $\pm 1.64 \%$ at $95 \%$ confidence level [3].

In social psychology, violence is differentiated from aggression. Aggression is defined as any behavior that is intended to harm another person who does not want to be harmed while violence is understood as aggression that has extreme physical harm as its goal, such as injury or death [4], [5]. According to this differentiation, a student who intentionally pushed another student with the intent to harm him or her will be considered as having committed aggression, not violence. Meanwhile, a student who beat another student, using a weapon or not, will be categorized as having committed violence.

Previous studies show that there are several types of aggression in school settings, including physical, verbal, psychological, sexual, and social or relational aggression. Some scholars suggest that the first three, i.e. physical, verbal and psychological aggression, are the most common [6]. Other scholars use different classification of aggression: overt-covert/relational [7], [8] and instrumental-reactive [9], [10].

Rapid development in the field of Information and Communication Technology (ICT) has brought about a new setting for aggression: cyber or online aggression [11], [12], [13], [14], [15]. Grigg defined cyber aggression as "...intentional harm delivered by the use of electronic means to a person or a group of people irrespective of their age, who perceive(s) such acts as offensive, derogatory, harmful, or unwanted" [16].

A 2017 survey of 10,000 adolescents with a range of 12-20 year-old in England found that $42 \%$ of respondents reported they had become victim of bullying on Instagram, 37\% on Facebook, and $31 \%$ on Snapchat. Another study found that in 2013 Facebook became the social media platform that was most frequently used for cyber-bullying [17].

This paper presents and discusses the results of a case study of student online aggression on social media. The study examines the following issues: (1) How frequent is online aggression among students? (2) What are forms of expression used to commit online aggression? (3) What are policies of the school and families to prevent and reduce student online aggression?

\section{Method}

This case study was conducted at MAN 2 Bogor City, West Java. The case was chosen on the basis of news reports on incidents of student violence in the city [18], [19], as well as information from Head of Section of Madrasah Education of Bogor City Office of Ministry of Religious Affairs (interview February 13, 2019). Field research was conducted from February 26 until March 12, 2019.

Data collection combined interviews and observation. To get a picture of the prevalence and types of student online aggression, questionnaires were administered to students. 455 of 1,159 students were randomly selected to participate to fill in paper questionnaires. The selection of samples also took into account proportions of students by gender and grade. Student online aggressive behavior was measured by student self-reports. They were asked with a question, "How often did you do to your fellow students the following acts?: (1) texting swear 
words/harsh words to other students, (2) spreading rumors/bad stories about other students, (3) uploading private pictures/videos to humiliate other students, and (4) threatening other students.

In addition to investigate a prevalence of student online aggression, this study also examines prevalence of student victimization and testimony regarding incidents of online aggression. The above list of aggressive acts is also asked to respondents with the following questions: "How often did you experience of such acts?" and "How often did you see or know such acts?" For all the questions, responses were given on 4-point scale: (1) never, (2) seldom, (3) fairly often, and (4) very often.

To obtain more information on student online aggression through social media, interviews were conducted with students, guidance counselling teachers, and school management. Interviews were also conducted with officials of Bogor City Office of Ministry of Religious Affairs and Commissioner of Regional Indonesian Child Protection Commission. Sample contents of social media containing aggressive messages and Guidance Counselling teachers' reports on incidents of student aggression were analyzed.

\section{Results}

\subsection{Demographic profile and use of social media}

From a total of 1,159 students of MAN 2 Bogor, 455 students were randomly selected to fill in a paper questionnaire. Total male respondents were $183(40.2 \%)$ and female were 272 $(59.8 \%)$, and they were proportionally distributed among three grades $(10,11$, and 12$)$. The average age of respondents was 16.4 year old. More than two-thirds of respondents took specialization in Math and Natural Sciences specialization, less than one-third in Social Sciences, and about $10 \%$ in (Islamic) religious studies. More than two-thirds of respondents were Sundanese, almost two-fifths were Javanese, and the rest were from various ethnic background. (For more complete information of the respondents' profile, see Table 1).

The average daily allowance respondents receive from their parents is IDR 33,000 . The most-often mode of transportation respondents use to go to the school are motorbike $(41.8 \%)$ and city public transportation $(35.4 \%)$. The rest include city bus, online-based motorcycle taxi, train, private cars, traditional motorcycle taxi and by-walk.

$99.1 \%$ of respondents reported that smart phones are the most-used type of mobile devices, followed by notebooks (61.1\%), personal computer or PC (20.7\%), and tablet computers (13\%). WhatsApp becomes the most active social media platform (used by $91.6 \%$ of respondents), followed by Instagram (83.3\%) and Line (67.7\%). Other social media platforms actively used by respondents include Youtube (59.8\%), Google+ (18.5\%), Twitter (14.3\%), Facebook (12.7\%), Snapchat (4.4\%), and Telegram (1.1\%).

Face-to-face interviews with a number of students confirmed that WhatsApp, Line, and Instagram are the most actively used social media platforms. The use of these social media, however, serves varied purposes. WhatsApp and Line are primarily used for the purpose of class communication. In each class, there are usually formed three groups of WhatsApp and Line: (1) a group consisting of all students and teachers, (2) a group of all-female students, and (3) a group of all-male students. In addition, there is a group consisting of parents and teachers. The latter group, usually created by a classroom teacher, is used to facilitate communication between 
Table 1. Profil of respondents.

\begin{tabular}{|c|c|c|c|}
\hline Sex & $\%$ & Age & Year \\
\hline Male & \multicolumn{2}{|c|}{ 40.2Min } & 14 \\
\hline Female & \multicolumn{2}{|c|}{ 59.8Max } & 20 \\
\hline & \multicolumn{2}{|r|}{ Mean } & 16.4 \\
\hline Grade & $\%$ & Specialization & $\%$ \\
\hline $\bar{X}$ & 33.8 & $\begin{array}{l}\text { Math \& Natural } \\
\text { Sciences }\end{array}$ & 62.4 \\
\hline XI & 33.0 & Social Sciences & 27.3 \\
\hline XII & 33.2 & Islamic Studies & 10.3 \\
\hline Ethinicity & $\%$ & Previous Education & $\%$ \\
\hline Sundanese & 68.8 & Junior High School & 68.6 \\
\hline Javanese & 19.6 & $\begin{array}{l}\text { Madrasah } \\
\text { Tsanawiyah }\end{array}$ & 30.8 \\
\hline Minang & 3.3 & NA & 0.7 \\
\hline Betawi & 2.4 & Elementary School & 82.9 \\
\hline Other & 5.9 & Madrasah Ibtidaiyah & 6.8 \\
\hline
\end{tabular}

parents and teachers regarding the progress of students' learning. Students themselves prefer to communicate each other using Line.

Lessons and friendship are the common topics students talk about in social media groups. A mixed group of male and female students mostly discusses the tasks they receive from teachers or gives information to fellow students who came late to the school or missed a class. In addition to a lessons-related topic, a group of all-females generally has a conversation about femininity and male-female relationship. These same topics also appear in a chat group of all males (Interviews with ST, student of grade 10, and HN, student of grade 11, March 3, 2019; interview with STN, student of grade 12, March 5, 2019).

Questionnaire results also showed the high frequency of the use of social media apps among students. $90.1 \%$ of respondents reported they use social media apps daily. $65 \%$ reported they search information through Internet browsing every day. Kinds of information respondents generally search related to lessons, both school work as well as exam training materials. Besides, they also browse information related to hobbies, such as music, films, games, and others (Field observation, March 8, 2019).

\subsection{Types and frequency of online aggression in social media}

This study considers student different roles in relation to online aggressive behavior on social media: (1) as a witness, (2) as a victim, and (3) as a perpetrator. A set of questions asked to respondents is as follows: (1) "How often did you see the following acts?" (2) How often did you experience the following acts?" (3) "How often did you do to your fellow students the following acts?"

A list of acts of aggression through social media given to respondents includes:

- Texting swear words/harsh words to other students;

- Spreading rumors/bad stories about other students;

- Uploading private pictures/videos to humiliate other students;

- Threatening other students. 
This research also investigates the frequency of student fights as a result of mutual mockery on social media. All responses were given on 4-point scale: (1) never, (2) seldom, (3) fairly often, and (4) very often.

Questionnaire results found that $57.6 \%$ of respondents had ever witnessed a student texting swear words or harsh words to another student on social media. $23.3 \%$ reported they had ever become a victim or got swear/harsh words from another student on social media. Meanwhile, $15.6 \%$ reported they have ever texted swear/harsh words to another student on social media.

Concerning acts of spreading rumors or bad stories about other students through social media, $45.7 \%$ of respondents reported they had become witnesses, $16.3 \%$ victims, and $9 \%$ perpetrators of such acts. As regards acts of uploading private pictures or videos to humiliate other students, $37 \%$ of respondents reported they had ever become witnesses, $27 \%$ victims, and $7.7 \%$ perpetrators of such acts.

Table 2. Frequencies of online aggression by respondent role.

\begin{tabular}{|c|c|c|c|c|c|c|}
\hline \multirow[b]{2}{*}{$\begin{array}{c}\text { Acts of Online Agression on Social } \\
\text { Media }\end{array}$} & \multicolumn{6}{|c|}{ Frequency (in \%) } \\
\hline & Never & Seldom & $\begin{array}{l}\text { Fairly } \\
\text { Often }\end{array}$ & $\begin{array}{l}\text { Very } \\
\text { Often }\end{array}$ & $\begin{array}{l}\text { Missing } \\
\text { value }\end{array}$ & Total \\
\hline \multicolumn{7}{|l|}{ As witness } \\
\hline Swearing/harsh words to other students & 42.4 & 38.2 & 15.8 & 3.3 & 0.2 & 100.0 \\
\hline $\begin{array}{l}\text { Spreading rumors/bad stories about other } \\
\text { students }\end{array}$ & 53.6 & 31.9 & 11.4 & 2.4 & 0.7 & 100.0 \\
\hline $\begin{array}{l}\text { Uploading private pictures/videos to } \\
\text { humiliate other students }\end{array}$ & 62.6 & 27.0 & 8.1 & 1.8 & 0.4 & 100.0 \\
\hline Threatening other students & 75.8 & 21.3 & 2.0 & 0.7 & 0.2 & 100.0 \\
\hline \multicolumn{7}{|l|}{ As victim } \\
\hline Swearing/harsh words to other students & 76.7 & 19.6 & 3.1 & 0.4 & 0.2 & 100.0 \\
\hline $\begin{array}{l}\text { Spreading rumors/bad stories about other } \\
\text { students }\end{array}$ & 83.5 & 14.7 & 1.5 & 0.0 & 0.2 & 100.0 \\
\hline $\begin{array}{l}\text { Uploading private pictures/videos to } \\
\text { humiliate other students }\end{array}$ & 84.2 & 14.3 & 1.3 & 0.0 & 0.2 & 100.0 \\
\hline Threatening other students & 94.1 & 5.1 & 0.7 & 0.0 & 0.2 & 100.0 \\
\hline \multicolumn{7}{|l|}{ As perpetrator } \\
\hline Swearing/harsh words to other students & 84.4 & 13.4 & 2.2 & 0.0 & 0.0 & 100.0 \\
\hline $\begin{array}{l}\text { Spreading rumors/bad stories about other } \\
\text { students }\end{array}$ & 91.0 & 8.4 & 0.7 & 0.0 & 0.0 & 100.0 \\
\hline $\begin{array}{l}\text { Uploading private pictures/videos to } \\
\text { humiliate other students }\end{array}$ & 91.9 & 7.0 & 0.7 & 0.0 & 0.4 & 100.0 \\
\hline Threatening other students & 97.8 & 2.2 & 0.0 & 0.0 & 0.0 & 100.0 \\
\hline
\end{tabular}


The final form of online aggression in social media investigated under this research is threatening other students. $24 \%$ of respondents reported they had ever witnessed this kind of online aggression. $5.7 \%$ had ever become victims, and $2.2 \%$ become perpetrators of such acts. (See Table 2 for more complete information).

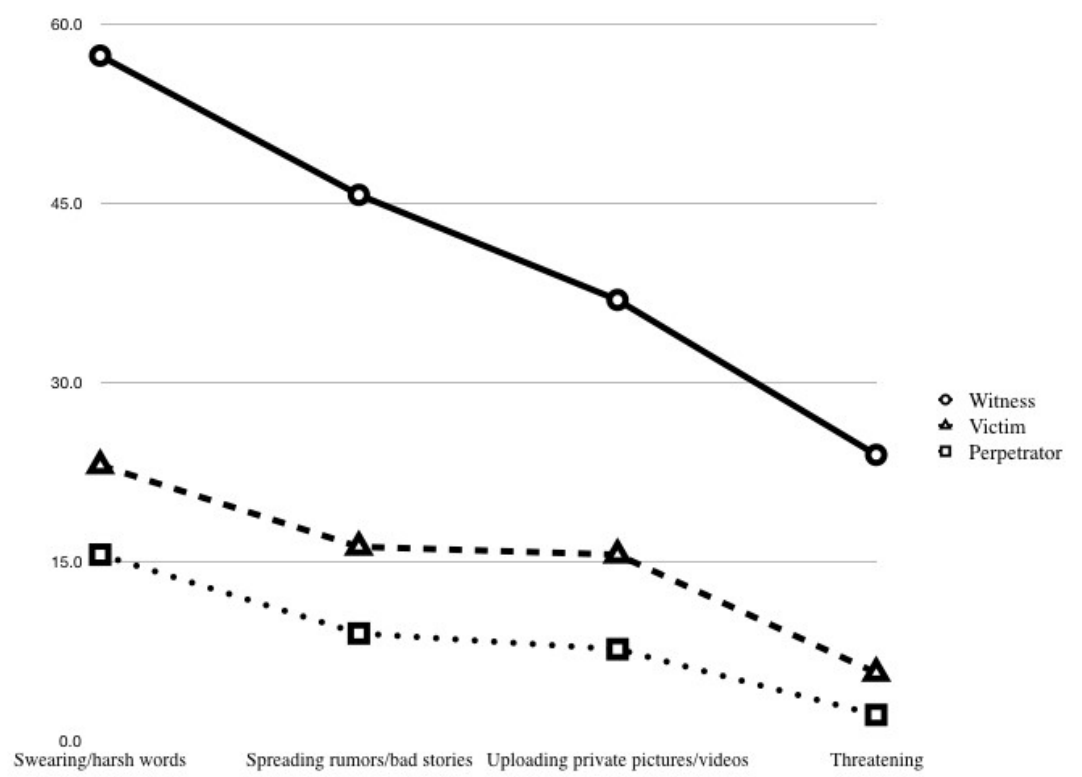

Fig. 1. Frequencies of student online aggression by respondent position and level of severity.

Figure 1. [1] presents interesting patterns of student aggression through social media. First, frequencies of online aggressive behaviors among students vary according to different perspectives of respondents: as witnesses, victims, or perpetrators. The highest frequency of student online aggressive behaviors, in all forms, was reported by witnesses, followed by victims and perpetrators. Second, frequencies of student online aggression decrease as the form of aggressive behavior becomes more severe. In this study, threatening acts appear as the most severe online aggression.

\subsection{Social media and student conflict}

This research also found that social media facilitate not only one-way aggression, known as bullying, but also two-way verbal aggression among students. $16.5 \%$ of respondents reported they had ever engaged in verbal disputes or mutual mockery on social media $(2.3 \%$ "fairly often", 14.3\% "seldom"). Furthermore, social media sometimes caused physical fights among 
students. 5.5\% of respondents reported they had ever engaged in physical fights with other students ( $0.4 \%$ "fairly often", $5.1 \%$ "seldom").

Results of face-to-face interviews with teachers showed that verbal disputes on social media could also happen after students had previously engaged in face-to-face physical or verbal aggression. Guidance counseling teachers rarely knew that online aggression or disputes had occurred among students until these aggression or disputes resulted in physical aggression or fights. (Interviews with Yayat Supriatna, Vice Head of Student Affairs of MAN 2 Bogor City, February 13, 2019; with Rahmawati, Linjar and Dede, Guidance Counselling teachers, February 14, 2019).

An example case of verbal aggression resulting in physical aggression leading to online aggression occurred at MAN 2 Bogor was a dispute between two classmates in the beginning of the first semester of 2019. The problem began when student A accused student B of taking someone else's belongings. Student B denied the accusation and then hit student A (Interview with HS, student of grade 10, March 2, 2019). Afterwards student A apologized to student B. However, student B felt that student A did not make a sincere apology. Student B then vented his pique by sending text messages and voice mail containing swear words and threat to student A. In his aggressive behavior, student B used swear words such as "anjing" (dog), "setan" (satan), "belagu" (ostentatious), "bangsat" (rotter) and "tengil" (suck). (Interview with IS, student of grade 10, March 11, 2019; researcher obtained from several students samples of text and voice messages containing swearing and threatening words).

Another case was when a group of junior students engaged in mutual mockery with their seniors, and the dispute continued to a "text war" on social media. As a result, both parties mobilized and they almost got in a fight. Because of this incidence, some windows were broken, although the fight itself could be prevented. (Interview with Yayat Supriatna, Vice Head of Student Affairs of MAN 2 Bogor City, February 13, 2019).

Threatening on social media may also lead to other aggressive behaviors, such as sexual abuse. Bogor City Regional Indonesian Child Protection Commission (KPAID) recorded a case in which a junior high school girl student received a threat from a boy student who demanded her to have a sexual intercourse with him. The case started when the girl initially got acquainted with the boy through Facebook. Their relation continued until they began exchanging nude photos of theirs. Later the boy demanded the girl to have a sexual intercourse with him. He made a threat to spread her nude photos if she refused to fulfill his demand. (Interview with Sumedi, Commissioner of Cybercrime Division of KPAID Bogor City, March 5, 2019).

\subsection{Expressions of online aggression on social media}

Ten types of verbally aggressive messages identified in a previous study are: character attacks, competence attacks, background attacks, physical appearance attacks, maledictions, teasing, ridicule, threats, swearing, and nonverbal emblems [20]. Several types of this verbal aggression were also found in social media-facilitated aggressive behavior. One type of verbal aggression found among students of MAN 2 Bogor City was body shaming. Example words of such aggression were "gendut" (fat) and "jalannya songgeng" (walked with showing off her butt). Such physical appearance attacks not only occurred in face-to-face interactions but also in group conversations on social media like WhatsApp. Social media-based aggressive expressions appeared in words like "sok iya" (show-off) and "sok paling..." (as if the most...). (Interview with G, student of grade 11, March 9, 2019).

Another type of online aggression was competence attacks. There was a case when a student invited his classmates to see a result of his work. However, they gave negative responses to his 
work by expressing words such as "aneh" (freak), "alay" (tacky), "lebay" (exaggerated), "goblok" (stupid), and "bego" (dumb). In WhatsApp group chats, students used disdaining words such as "sok pintar" (tried to sound smart), "alay" (tacky), "belagu" (swank), "ke laut aja lu" (lit. just go to the sea!) and "gak mutu" (poor quality). (Interview with HK, student of grade 11, March 4, 2019).

A student told there was another student who frequently bullied his fellow students, in faceto-face interaction as well as through social media, in the forms of physical appearance, competence and social status insults. This made the bullied student felt hurt and inferior (Interview with N, student of grade 11, February 27, 2019). However, when the bullies was interviewed, he denied that he had ever engaged in bullying other students. (Interview with SL, student of grade 11, March 12, 2019).

In some cases, victims of bullying initially considered aggression on social media as jokes or pranks. However, as the acts of aggression occurred repeatedly and frequently, these hurt the victims' feelings and led to disputes on social media as well as physical clashes. In some other cases, verbal aggression was intentionally conducted to hurt other feelings. For example, such acts were directed towards students who often missed classes or low-performing students. Quarrels about girlfriends or boyfriends could also become the cause of verbal aggression. Examples of words used are "tolol" (stupid), "bego" (fool), "goblok" (idiot), "kurang micin" (lit. overconsumption of MSG, but it is used as a slang word for "dumb"), "banci" (sissy) (labelling for boy students who do not smoke), "pepek" (vagina), and "anjing" (dog). (Interviews with ST, student of grade 10, and HN, student of grade 11, March 3, 2019; with STN, student of grade 12, March 5, 2019).

Verbal as well as online aggressive acts are dynamic. It could start as an act of one person toward another person and subsequently become an act of several persons toward one person or group disputes. It is similar with physical aggression as it could develop from one-on-one fights to many-on-one fights. Verbal as well as online aggression are also dynamic because both could result in physical aggression.

\subsection{School and family policies}

What are policies of schools and families to prevent and reduce student online aggression on social media? This study found that MAN 2 Bogor City has no specific policies and strategies to prevent student online aggression. The school also has no specific programs to promote healthy use of internet and smartphones by students. (Interview with Yayat Supriatna, Vice Head of Student Affairs of MAN 2 Bogor City, February 13, 2019).

On the part of students, they tend not to report to teachers when they got social media messages containing mild-to-moderate aggressive expressions, such as teasing, swearing, or humiliating images/videos. Instead, students tend to tell their friends when they experience such aggressive behaviors. Only when they obtain threatening messages, they report such messages to teachers.

Table 3 shows that $77.4 \%$ of respondents would tell their friends if they become victims of cursing or swearing. $77.1 \%$ of respondents would do the same if they get teasing or ridcule messages on social media, and $64.4 \%$ of respondents if they receive humiliating pictures or 
videos. However, less than half of respondents would inform their friends if they receive threat messages while $54.1 \%$ preferred to report such messages to their teachers.

These findings inform us that mild-to-moderate online aggressive messages are difficult to know. Teachers rarely get information on verbal or online aggression unless these kinds of aggression have developed into threats or physical aggressive acts.

This case study also reveals that parents are less-informed with online aggressive acts because they are not the main party to whom students tell their experience of such acts. Like teachers, parents would know if their children have experienced verbal and online aggressive acts when such acts already resulted in physical aggression. (Interview with HS, student of grade 10, March 2, 2019).

Based on interviews with several parents, it was found that parents tend to give more freedom to their adolescents regarding the use of smartphones and access to the internet. Parents believe that they are able to use smartphones and access the internet wisely. Their main warning for their adolescents is no access to porn and other bad websites. (Interviews with parents of DS, DA, and J, March 7, 2019). This confirms the questionnaire result that $74.1 \%$ of respondents reported their parents forbid them to access certain bad websites, such as porn or gambling websites. $92.7 \%$ reported their parents do not limit the use of smartphones in a week. Only

Table 3. Parties to whom victims of online aggression report by type of aggression (in \%), multiple responses.

\begin{tabular}{lrrrrr}
\hline $\begin{array}{l}\text { Acts of Online } \\
\text { Aggression }\end{array}$ & Friends & Teachers & Parents & $\begin{array}{c}\text { Other } \\
\text { Families }\end{array}$ & NA \\
\hline Cursing/Swearing & 77.4 & 24.4 & 4.2 & 3.7 & 6.6 \\
$\begin{array}{l}\text { Teasing/Ridicule } \\
\begin{array}{l}\text { Humiliating } \\
\text { images/videos }\end{array}\end{array}$ & 64.1 & 33.8 & 4.8 & 4.6 & 4.6 \\
Threats & 48.8 & 54.1 & 12.1 & 5.1 & 8.4 \\
\hline
\end{tabular}

$29.2 \%$ of respondent reported that their parents limit the hours of smartphone use in a day and $35.8 \%$ reported that their parent put a limit on the monthly amount of money to buy internet access.

\section{Discussion}

One of important findings of this research is that the prevalence of online aggression was reported differently by respondents, depending on his or her relation to the incidence of aggression. Frequencies of aggression incidents reported by perpetrators tend to smaller than those reported by victims. This finding is similar to what were found in previous studies [21], [22]. However, the previous two studies did not take into account the position of witnesses. This 
present study found that frequencies of aggression incidents reported by respondents as witnesses are higher than those reported by both perpetrators and victims. A 'neutral' position of witnesses in relation to aggression incidents perhaps becomes an important factor that contributed to the relative higher frequency of aggression reported by witnesses. It is because this neutrality gives respondents no risk to report aggression incidents.

Another important finding of this study was that frequencies of online aggression incidents reportedly varied with levels of severity of aggressive acts. Respondents tended to report smaller frequencies of severe online aggressive behavior, such as threatening, compared to those of mild or moderate aggression. As this pattern was reported by all respondents, whether they were witnesses, victims or perpetrators, it is most likely that mild-to-moderate online aggressive incidents were more prevalent than severe ones.

This case study also found that types of online aggression resemble those of verbal aggression. Physical appearance attacks, competence attacks, swearing, teasing, ridicule and threatening are among the most frequent types appeared in online aggression. Like face-to-face verbal aggressions, online aggression social media oftentimes leads to physical fights or aggression.

As face-to-face verbal aggression, online aggressive acts can have serious consequences on students' psychological development and academic performance. However, this study found that this kind of aggression has not yet received proper attention from both the school as well as parents. This may explains the lack of appropriate school's policies, strategies and programs that are devised to prevent and reduce student online aggression.

Considering students' tendency to inform experience of aggression to their friends rather than to teachers and parents, it suggests a potential role of friendship in preventing and reducing student online aggression. This supports the findings of Hodges et al. [23] that demonstrated the importance of peer friendships in preventing an escalating cycle of peer abuse.

Therefore, it is important to take into consideration the role of student friendship in formulating policies and strategies for the prevention and reduction of student aggression. Students' involvement might contribute to early detection and early warning of verbal as well as online aggressive behaviors that can provide a basis for early responses and intervention. Besides, the school and parents need to establish collaborative efforts to create a sustainable and effective intervention strategies to prevent and reduce student aggressive behaviors, including those are facilitated by social media.

\section{Conclusion}

This case study examines student aggressive behavior on social media, which is named by scholars as 'online aggression' or 'cyber aggression'. By taking into account different positions of respondents in relation to aggression incidents, this study found that higher frequencies of student online aggression were reported by witnesses, followed by victims and perpetrators. The higher frequencies of online aggression reported by witnesses may correlate with a neutral, norisk position that respondents enjoy in reporting online aggressive behavior.

In this study, it is found that types and expressions of online aggression are relatively similar to those of face-to-face verbal aggression. The similarity is also found in terms of consequences that both verbal and online aggression may bring about, which is, direct confrontation or physical fights. 
A lack of appropriate school policies for the prevention and reduction student aggressions is another important finding from this study. There is a pressing need for schools to work collaboratively with parents and other stakeholders to formulate proper policies and effective strategies for preventing and reducing all types of student aggression.

Acknowledgment. I am grateful to Jakarta Office of Religious Research and Development (Balai Litbang Agama Jakarta) which provided funds for this research. I am also grateful to Bogor City Office of Ministry of Religious Affairs which facilitated this research. My gratitude is also extended to the head and teachers of MAN 2 Bogor City, who provided support for this research. Special thanks go to Yayat Spriyatna, Vice Head of Student Affairs of MAN 2 Bogor City. I would like also to thank Yufi Adriani and Abdul Mujib, respectively a lecturer and a professor at the Faculty of Psychology of State Islamic University Syarif Hidayatullah Jakarta, and Rudy Harisyah Alam, Chief of Quality Assurance Team of Jakarta Office of Religious Research and Development, for their valuable comments. The original version of this paper was already presented at a seminar in Jakarta, April 8, 2019. For this, I am grateful to participants of the seminar for their comments. Despite valuable comments from many people, any errors in this paper are the sole responsibility of the author

\section{References}

[1] Yusuf, Y.: Sepanjang 2018, Delapan Pelajar di Jakarta Tewas Akibat Tawuran, 16 December 2018 [Online]. Available at: https://tekno.kompas.com/ (Accessed: 6 February 2019).

[2] Firmansyah, M. J. 2018. KPAI: Tawuran Pelajar 2018 Lebih Tinggi Dibanding Tahun Lalu, 12 September 2019 [Online]. Available at: https://metro.tempo.co/ (Accessed: 6 February 2019).

[3] Alam, R.H.: Pendidikan Agama di Sekolah dan Perilaku Kekerasan Pelajar Di Jakarta, Bekasi, Depok dan Tangerang. Laporan Hasil Survei. Jakarta: Balai Litbang Agama Jakarta (2014).

[4] Bushman, B.J., and Huesmann, L.R.: Aggression. In S. T. Fiske, D.T. Gilbert, and G. Lindzey (Eds.), Handbook of Social Psychology, 5th edition, pp. 833-863. New York: John Wiley \& Sons (2001).

[5] Levinson, D.: Aggression and Conflict: A Cross-cultural Encyclopedia. California: ABC-CLIO, Inc. (1994).

[6] Kozina, Ana.: "Measurement of Students' Aggressive Behavior in School Settings." Paper presented at the European Conference on Educational Research, University of Ghent, 19-21 September 2007.

[7] Crick, N. R.: The role of overt aggression, relational aggression, and prosocial behavior in the prediction of children's future social adjustment. Child Development, 67, pp. 2317- 2327 (1996).

[8] Lagerspetz, K. M. J., Bjo r̈kqvist, K., \& Peltonen, T.: Is indirect aggression typical of females? Gender differences in aggressiveness in 11- to 12-year-old children. Aggressive Behavior, 14, pp. 403414 (1988).

[9] Dodge, K. A., \& Coie, J. D.: Social information-processing factors in reactive and instrumental aggression in children's play-groups. Journal of Personality and Social Psychology, 53, pp. 1146-1158 (1987).

[10] Day, D. M., Bream, L. A., \& Pal, A.: Instrumental and reactive aggression: An anal- ysis of subtypes based on teacher perceptions. Journal of Clinical Child Psychology, 21, pp. 210-17 (1992).

[11] Grigg, D.W.: Cyber-Aggression: Definition and Concept of Cyberbullying. Australian Journal of Guidance and Counselling 20 (2), pp. 143-56 (2010).

[12] Corcoran, L., Mc Guckin, C. and Prentice, G.: Cyberbullying or Cyber Aggression?: A Review of Existing Definitions of Cyber-Based Peer-to-Peer Aggression. Societies 5: 245-255 (2015); doi:10.3390/soc5020245. 
[13] Olweus, D.: Cyberbullying: An overrated phenomenon? Eur. J. Dev. Psychol. 9, pp. 520-538 (2012).

[14] Smith, P.K.: Cyberbullying: Challenges and opportunities for a research program-A response to Olweus. Eur. J. Dev. Psychol. 2012, 9, pp. 553-558 (2012).

[15] Dodey, J.J., J. Pyzalski, and D. Cross.: "Cyberbullying versus face to face bullying: A Theoretical and Conceptual Review." Journal of Psychology 217 (4), pp. 182-88 (2009).

[16] Grigg, D.W.: Cyber-Aggression: Definition and Concept of Cyberbullying. Australian Journal of Guidance and Counselling 20, (2). p. 152 (2010).

[17] Bohang, F.K.: Instagram Jadi Media "Cyber-Bullying” Nomor 1, 21 July 2017.[Online]. Available at: https://metro.sindonews.com/ (Accessed: 6 February 2019).

[18] Sudarno, A.: Tawuran Pelajar di Bogor, Siswa SMP Tewas, 15 September 2018 [Online]. Available at: https://www.liputan6.com/ (Accessed: 6 February 2019).

[19] Liputan6.: Libur Sekolah Mau Tawuran, Pelajar Bogor dan Depok Diamankan Petugas, 27 January 2019 [Online]. Available at: https://www.liputan6.com/ (Accessed: 6 February 2019).

[20] Infante, D. A., Sabourin, T. C., Rudd, J. E., \& Shannon, E. A.; Verbal Aggression in Violent and Nonviolent Marital Disputes. Communication Quarterly, 38, 361-371 (1990).

[21] Alam, R.H.: Pendidikan Agama di Sekolah dan Perilaku Kekerasan Pelajar Di Jakarta, Bekasi, Depok dan Tangerang. Laporan Hasil Survei. Jakarta: Balai Litbang Agama Jakarta (2014).

[22] Dodey, J.J., J. Pyzalski, and D. Cross.: "Cyberbullying versus face to face bullying: A Theoretical and Conceptual Review." Journal of Psychology 217 (4), pp. 182-88 (2009).

[23] Hodges, E. V. E., Boivin, M., Vitaro, F., \& Bukowski, W. M.; The power of friendship: Protection against an escalating cycle of peer victimization. Developmental Psychology, 35(1), pp. 94-101 (1999). http://dx.doi.org/10.1037/0012-1649.35.1.94. 